
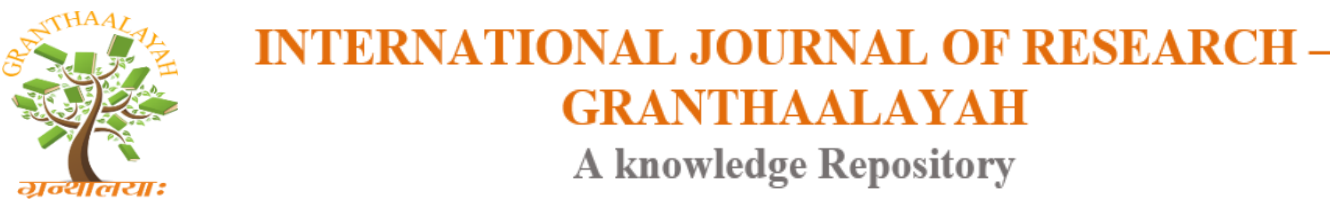

Social

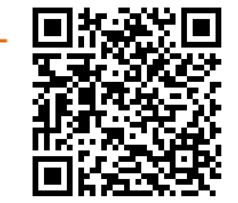

\title{
INFLUENCE OF INFORMATION LITERACY ON STUDENTS OF G.B. PANT UNIVERSITY OF AGRICULTURE \& TECHNOLOGY, PANTNAGAR: A CASE STUDY
}

\author{
Meetu Gupta*1, Rakesh Pant ${ }^{2}$ \\ ${ }^{* 1,2}$ Research Scholar, Kumaun UniversityNainital, India
}

DOI: https://doi.org/10.29121/granthaalayah.v5.i2.2017.1738

\begin{abstract}
Information literacy is lesson of the fundamental entitlement of all citizens in the world to freedom of expression and the right to information. It is instrumental in building and sustaining democracy. University library is continuously striving to fulfill the needs of its broad campus incorporating latest Information \& Communication Technology (ICT). Knowledge of PG students and research scholars about the information, information sources, university library, information searching, library consortia, internet etc. assessed in the present study. It has been find out that the students are comfortable in identifying the information need, searching the information, locating the information, finding the information and using the information. They save their time in finding the information.
\end{abstract}

Keywords: Information Literacy; Searching Skills; Internet.

CITE THIS ARTICLE: Meetu Gupta, and Rakesh Pant. (2017). "INFLUENCE OF INFORMATION LITERACY ON STUDENTS OF G.B. PANT UNIVERSITY OF AGRICULTURE \& TECHNOLOGY, PANTNAGAR: A CASE STUDY." International Journal of Research - Granthaalayah, 5(2), 266-278. 10.29121/granthaalayah.v5.i2.2017.1738.

\section{Introduction}

In the present age of digital continuation impression and development has add powerful generator of barring no one country. The information and knowledge are playing practice role in financial condition of barring no one country. In the present age of World Wide Web, information and information sources have been reproduced at as a matter of fact fast pace. There are greater than 50000 accurate journals published for the most part everywhere the world. Apart from these, numerous at variance reference sources love books, websites etc. are accessible in print and digital format. In this digital reality, World Wide Web is major sources to access the information. In India, most of the universities and colleges have been efficient to fulfill the information needs of their users at the hand of consortium mode. Most of the students and research scholars are accessing greater than thousands of scholarly journals under consortium 
pattern in India. Information searching tools appreciate Google, Yahoo, Bing etc. have acquire the favorite searching tools for result the information by students of school, colleges and other users. Nowadays thousands of open access journals and books are by the same token at hand for users. The picture is that users are now overloaded from information. In the present time, the problem is not the lack of information but the main problem is significant use of the available information and information sources. In approximately cases users find difficulties to determine the right information due to lack of search skills. The information literacy (IL) plays the significant role in proper utilization of information, developing search skill and inception of knowledge.

Information literacy is object of the integral entitlement of every citizen, in every country in the world, to assent of allusion and the right to information. It is instrumental in building and sustaining democracy. It is a manner of personal empowerment. It provides them with the flexibility to devise their own arguments and to experience of the search for knowledge. It also creates in fresh students the motivation for learning. Information literacy forms the essence for lifelong learning. It is commonplace to all disciplines and to all levels of learning. Information literacy has been most zoned by various authors and intuitions. According to The American Library Association (1989) information literacy is to be information literate an individual must recognize when information is inadequate and have a flexibility to reside, evaluate and manage effectively the information needed. Ultimately information literate people are those who have learned at which point to learn. According to Sanford (2000), information literacy is a practice of recommending information into meaning, understanding, and new ideas. This process would require students to recognize the sanity behind using information as readily as truly knowing the exact procedures of conducting the information search. The original use of the term "information literate" was firstly used by Paul Zurkowski, who in 1974 indicated that it meant people who were efficient in applying information resources to their function, using these skills and tools to solve problems (Maughan, 2001). Information literacy has been defined by the Chartered Institute of Library and Information Professionals in the UK as "knowing when and why you require information, to what place to greet it, and at which point to evaluate, use and communicate it in an of good repute manner" (CILIP, 2004). The Alexandria Proclamation furthermore described that information literacy needs to be approaching not only in recurrence to education, but also in the broader context of work, civil community, and health and wellbeing (Garner, 2006).

\section{G. B. Pant University of Agriculture and Technology, Pantnagar (Gbpuat)}

GBPUAT was established on 17th November, 1960 as a first Agriculture University of India. The University was dedicated to the Nation by the first Prime Minister of India Pt Jawaharlal Nehru. This University is named on the Pt. Govind Ballabh Pant. He was the great freedom fighter in un-independent India of Kumaun zone. University has produced multiple stars in the trade of agriculture and is still continuing by all of its directive of producing effective manpower for the country. It performs a bold and innovative education programme to meet the new challenges of scientific manpower, notable and relevant research and efficient extension services. Since 9th March 2000, after partition of Uttar Pradesh State, the university is in Uttaranchal State i.e. Uttarakhand. Recently in the Sept. 2011, the Utttarakand Government has established "Uttarakhand University of Horticulture \& Forestry, Bharsar" after merging two colleges of 
GBPUAT (i.e. The Veer Chandra Singh Garhwali College of Horticulture, Bharsar (PauriGarwal) and College of Forestry \& Hill Agriculture, Rani Chauri).

\section{Literature Review}

Many studies and reports have been published on information literacy, lists of competencies, and descriptions of information literacy programmes and courses. The most common example of an information literacy assessment technique is the use of survey questionnaire instruments, using multiple-choice, fill-in, or matching questions (Dunn, 2002). It is difficult to cover many of the information literacy concepts or to assess the success of the instruction when only a short time is available to the teaching librarians (Owusu-Ansah, 2004). Betsy Barefoot (2006) discusses the perception of first year college students According to him campus libraries are largely irrelevant to their lives. He suggested ways to make library instructions an integral part of the courses. According to Ameet Doshi (2006) integrating a gaming element into library skills instruction as a way to improve learning and portray libraries in a less boring light. Useful source of assessment techniques is provided in a book on information literacy assessment for academic librarians which provides advice about choosing an assessment tool (Radcliff et al., 2007). Standardized measures of information literacy skills and knowledge may show how well the student understands the theory of how to do research, but this is not the same as the student actually demonstrating this understanding by actually doing the research (Sonley et al., 2007). Chauhan and Murthy (2006) overviewed the awareness programmes initiated by INFLIBNET for information literacy throughout the country under UGC-Infonet: E-Journals consortium. They describe the efforts INFLIBNET had been extending to make academicians aware and train to use the e-resources available through consortium up to optimum level. Agriculture universities started teaching library skills way back in 1970s with Indira Gandhi Krishi Vishvidhalaya, Raipur (MP) being the first university followed by GB Pant University of Agriculture and Technology in 1976, and Marthwada Agriculture University Maharastra (Singh and Klingenberg 2012).

\section{Need and Scope of the Study}

The information literacy is required to educate the users for recognizing the information require, locating \& evaluating the quality information, storing \& retrieving information, making skilled \& ethical use of information, applying the information in creating \& communication knowledge. Information literacy ensures anticipation and sense-making among doubtful information-seekers. As the information and information sources have increased absolutely fast in diverse forms and formats all around the world. Indian academic and research libraries are providing access to most of the journals in digital form while books in printed form. These libraries are providing steady services as readily as modern computerized services. Information literacy plays the significant role in this environment to educate the library users. Users need to interest the distinctive services of libraries in ICT environment through information literacy. 


\section{Objectives of the Study}

The main objective of the study is to analyze the influence of information literacy on students at G.B. Pant University of Agriculture \& Technology, Pantnagar. The objective has been studied with the help of following sub-objectives spelt out as under:

- To assess the necessary skills of the students to identify, locate and evaluate the information

- To assess the knowledge of the students about information sources and university library.

- To assess the knowledge of the students about library consortia and internet etc.

\section{Research Methodology}

A survey method was adapted for the present study. A questionnaire is prepared on the basis of objectives of the study and contents of information literacy to assess the information literacy knowledge of students of the GBPUAT. Data is collected through questionnaires from both the categories of students i.e. Post Graduate Students and Research Scholars. The collected data is compiled in tabular form. MS Excel, MS Word and other software is used to analyze the collected data. A comparative study is carried out on the basis of collected data.

\section{Results and Discussion}

Approximately 150 questionnaires were distributed among the students to know the influence of information literacy on PG students and research scholars of GBPUAT. Out of 150, 126 responses were received; 27 from Research Scholar and 99 from PG students. The analytical study given in the following tables.

Online Public Access Catalogue (OPAC) or printed card catalogue helps students in finding and locating books in the library. Table-1 shows that $81.48 \%$ research scholars have given right choice while $50.51 \%$ students from the PG have given right choice for finding books in the library. The data shows that right choice in finding books in the library is about $31 \%$ higher in research scholars as compared to PG students. The study shows that $45.45 \%$ PG students search books directly from the bookshelf which are wasting their valuable time.

Table 1: Finding a textbook in the library

\begin{tabular}{|c|c|c|c|c|c|}
\hline Students & $\begin{array}{c}\text { Indexing/ } \\
\text { Abstracting } \\
\text { Databases }\end{array}$ & $\begin{array}{c}\text { OPAC/Printed } \\
\text { Catalogue }\end{array}$ & $\begin{array}{c}\text { Search book } \\
\text { directly from } \\
\text { Bookshelf }\end{array}$ & $\begin{array}{c}\text { Don't } \\
\text { know }\end{array}$ & Total \\
\hline $\begin{array}{c}\text { Research } \\
\text { Scholars }\end{array}$ & $\begin{array}{c}1 \\
(3.70 \%)\end{array}$ & $\begin{array}{c}22 \\
(81.48 \%)\end{array}$ & $\begin{array}{c}4 \\
(14.82 \%)\end{array}$ & $\begin{array}{c}0 \\
(0 \%)\end{array}$ & $\begin{array}{c}27 \\
(21.43 \%)\end{array}$ \\
\hline PG & 4 & 50 & 45 & 0 & 99 \\
students & $(4.04 \%)$ & $(50.51 \%)$ & $(45.45 \%)$ & $(0 \%)$ & $(78.57 \%)$ \\
\hline Total (\%) & 5 & 72 & 49 & 0 & 126 \\
$(3.97 \%)$ & $(57.14 \%)$ & $(38.89 \%)$ & $(0 \%)$ & $(100 \%)$ \\
\hline \hline
\end{tabular}


Subject is the right choice while searching information from OPAC or any other database. As shown in table-2 that $77.78 \%$ research scholars and $47.47 \%$ PG students have expressed that subject is their first choice in searching information. Overall only $53.97 \%$ students have given the right answer about searching information. The data shows that $42.43 \%$ PG students have given the title as a first choice of searching information after subject.

Table 2: Choice of searching information

\begin{tabular}{|c|c|c|c|c|c|}
\hline Students & Author & Title & Subjects & Don't know & Total \\
\hline Research & 4 & 2 & 21 & 0 & 27 \\
Scholars & $(14.81 \%)$ & $(7.41 \%)$ & $(77.78 \%)$ & $(0 \%)$ & $(21.43 \%)$ \\
& & & & & \\
\hline PG students & 10 & 42 & 47 & 0 & 99 \\
& $(10.10 \%)$ & $(42.43 \%)$ & $(47.47 \%)$ & $(0 \%)$ & $(78.57 \%)$ \\
\hline Total (\%) & 14 & 44 & 68 & 0 & 126 \\
& $(11.11 \%)$ & $(34.92 \%)$ & $(53.97 \%)$ & $(0 \%)$ & $(100 \%)$ \\
\hline
\end{tabular}

Preference in use of print verses digital form of information sources is always the subject of debate. We have asked two questions i.e. about OAPC and online journals to know the student's choice of digital or print format. The study shows that $100 \%$ research scholars prefer the OPAC format and total $89.68 \%$ students prefer the OPAC (Table-3). It indicates that majority of students prefer the digital form of catalogue (i.e. OPAC) as compared to print format. We can say that OPAC is very useful for providing the desired information and save the time of readers.

Table 3: Preference of Catalogue format

\begin{tabular}{|l|l|l|l|}
\hline \multicolumn{1}{|c|}{ Students } & $\begin{array}{l}\text { Printed catalogue in } \\
\text { card form }\end{array}$ & \multicolumn{1}{|c|}{$\begin{array}{c}\text { Online Public Access } \\
\text { Catalogue (OPAC) }\end{array}$} & \multicolumn{1}{c|}{ Total } \\
\hline $\begin{array}{l}\text { Research } \\
\text { Scholars }\end{array}$ & 0 & 27 & 27 \\
& $(0 \%)$ & $(100 \%)$ & $(21.43 \%)$ \\
\hline PG students & 13 & 86 & 99 \\
& $(13.13 \%)$ & $(86.87 \%)$ & $(78.57 \%)$ \\
\hline Total (\%) & 13 & $\begin{array}{l}113 \\
(89.68 \%)\end{array}$ & $\begin{array}{l}126 \\
(100 \%)\end{array}$ \\
\hline
\end{tabular}

Bibliography is a list of books, articles, and other sources. The bibliography appears at the end of paper of in the form of document. Most of the students i.e. 88.10\% know about the bibliography (Table-4). There is no significant difference between research scholars (96.30\%) and PG $(85.86 \%)$ students in the correct response about bibliography.

Table 4: Knowledge of bibliography

\begin{tabular}{|l|l|l|l|l|l|}
\hline Students & $\begin{array}{l}\text { List of } \\
\text { Persons }\end{array}$ & $\begin{array}{l}\text { List of } \\
\text { Addresses }\end{array}$ & List of Books & Don't know & Total \\
\hline $\begin{array}{l}\text { Research } \\
\text { Scholars }\end{array}$ & 1 & 0 & 26 & 0 & 27 \\
& $(3.70 \%)$ & $(0 \%)$ & $(96.30 \%)$ & $(0 \%)$ & $(21.43 \%)$ \\
\hline
\end{tabular}




\begin{tabular}{|l|l|l|l|l|l|}
\hline PG students & 5 & 4 & 85 & 5 & 99 \\
& $(5.05 \%)$ & $(4.04 \%)$ & $(85.86 \%)$ & $(5.05 \%)$ & $(78.57 \%)$ \\
\hline Total $(\%)$ & 6 & 4 & 111 & 5 & 126 \\
& $(4.76 \%)$ & $(3.17 \%)$ & $(88.10 \%)$ & $(3.97 \%)$ & $(100 \%)$ \\
\hline
\end{tabular}

The University Library, Pantnagar has been published Indian Agricultural Index (IAI) in print as well as online on the basis of Indian agricultural science journals received at the library. It was asked to students about the publisher of IAI. It is observed from table-5 that $70.38 \%$ research scholars know about the publisher of IAI while only $18.18 \%$ PG students know about the publisher of IAI.

Table 5: Knowledge of Indian Agricultural Index

\begin{tabular}{|l|l|l|l|l|l|}
\hline \multicolumn{1}{|c|}{ Students } & \multicolumn{1}{|c|}{$\begin{array}{c}\text { University } \\
\text { Library, } \\
\text { Pantnagar }\end{array}$} & $\begin{array}{l}\text { ICAR, New } \\
\text { Delhi }\end{array}$ & $\begin{array}{c}\text { IARI, } \\
\text { Library }\end{array}$ & $\begin{array}{c}\text { Don't } \\
\text { know }\end{array}$ & \multicolumn{1}{|c|}{ Total } \\
\hline $\begin{array}{l}\text { Research } \\
\text { Scholars }\end{array}$ & $\begin{array}{l}19 \\
(70.38 \%)\end{array}$ & $\begin{array}{l}4 \\
(14.81 \%)\end{array}$ & $\begin{array}{l}4 \\
(14.81 \%)\end{array}$ & $\begin{array}{l}0 \\
(0 \%)\end{array}$ & $\begin{array}{l}27 \\
(21.43 \%)\end{array}$ \\
\hline PG students & $\begin{array}{l}18 \\
(18.18 \%)\end{array}$ & $\begin{array}{l}34 \\
(34.34 \%)\end{array}$ & $\begin{array}{l}4 \\
(4.04 \%)\end{array}$ & $\begin{array}{l}43 \\
(43.44 \%)\end{array}$ & $\begin{array}{l}99 \\
(78.57 \%)\end{array}$ \\
\hline Total (\%) & $\begin{array}{l}37 \\
(29.37 \%)\end{array}$ & $\begin{array}{l}38 \\
(30.15 \%)\end{array}$ & $\begin{array}{l}43 \\
(6.35 \%)\end{array}$ & $(34.13 \%)$ & $\begin{array}{l}126 \\
(100 \%)\end{array}$ \\
\hline
\end{tabular}

Class number of document represents the subject of documents. The library follows the Dewey Decimal Classification (DDC) scheme for classifying documents. The table-6 shows that overall $21.43 \%$ students answered right about the representation of class number of document(s). It is observed that $62.96 \%$ research scholars replied right answer while only $10.10 \%$ PG students replied correctly about the class number representation of documents in the library. It is also observed that overall $34.13 \%$ students don't know about class number.

Table 6: Class Number of Book/Documents represents

\begin{tabular}{|l|l|l|l|l|l|}
\hline Students & $\begin{array}{c}\text { Author of } \\
\text { Books/ } \\
\text { Documents }\end{array}$ & $\begin{array}{c}\text { Subject of } \\
\text { Books/ } \\
\text { Documents }\end{array}$ & $\begin{array}{l}\text { Title of Books/ } \\
\text { Documents }\end{array}$ & $\begin{array}{c}\text { Don't } \\
\text { know }\end{array}$ & Total \\
\hline $\begin{array}{l}\text { Research } \\
\text { Scholars }\end{array}$ & $\begin{array}{l}17 \\
(3.70 \%)\end{array}$ & $(62.96 \%)$ & $\begin{array}{l}7 \\
(25.93 \%)\end{array}$ & $\begin{array}{l}2 \\
(7.41 \%)\end{array}$ & $\begin{array}{l}27 \\
(21.43 \%)\end{array}$ \\
\hline PG students & $\begin{array}{l}6 \\
(6.06 \%)\end{array}$ & $\begin{array}{l}10 \\
(10.10 \%)\end{array}$ & $\begin{array}{l}42 \\
(42.42 \%)\end{array}$ & $\begin{array}{l}41 \\
(41.42 \%)\end{array}$ & $\begin{array}{l}99 \\
(78.57 \%)\end{array}$ \\
\hline Total (\%) & $\begin{array}{l}27 \\
(5.55 \%)\end{array}$ & $\begin{array}{l}49 \\
(38.89 \%)\end{array}$ & $\begin{array}{l}43 \\
(34.13 \%)\end{array}$ & $\begin{array}{l}126 \\
(100 \%)\end{array}$ \\
\hline
\end{tabular}

Some of the questions were asked about awareness of national information sources from the students. It was found that $74.07 \%$ research scholars and $47.47 \%$ PG students know about ETD (Electronic Theses \& Dissertation) (Table 7.1). Krishi Prabha is national project for digitization 
all the doctorate thesis of Indian agricultural universities from the year 2000-2007. After the year 2007, the digital copy of all the thesis of India agricultural universities will be submitted in digital born form to Krishi Prabha. Under this project, IP (Internet Protocol) based access of digital thesis is provided to all the agricultural universities and ICAR Institutions. The study shows that $70.37 \%$ research scholars and $24.24 \%$ PGstudents are aware about Krishi Prabha (Table 7.2).

Table 7.1: ETD

\begin{tabular}{|l|l|l|l|l|l|}
\hline Students & \multicolumn{1}{|c|}{$\begin{array}{c}\text { Electronic } \\
\text { Theses \& } \\
\text { Dissertation }\end{array}$} & $\begin{array}{c}\text { Electronic } \\
\text { Digit Text }\end{array}$ & $\begin{array}{l}\text { Electronic } \\
\text { Transfer } \\
\text { Digit }\end{array}$ & $\begin{array}{c}\text { Don't } \\
\text { know }\end{array}$ & Total \\
\hline $\begin{array}{l}\text { Research } \\
\text { Scholars }\end{array}$ & $\begin{array}{l}20 \\
(74.07 \%)\end{array}$ & $\begin{array}{l}5 \\
(18.52 \%)\end{array}$ & $\begin{array}{l}0 \\
(0 \%)\end{array}$ & $\begin{array}{l}2 \\
(7.41 \%)\end{array}$ & $\begin{array}{l}27 \\
(21.43 \%)\end{array}$ \\
\hline PG students & $\begin{array}{l}47 \\
(47.47 \%)\end{array}$ & $\begin{array}{l}20 \\
(20.20 \%)\end{array}$ & $\begin{array}{l}9 \\
(9.09 \%)\end{array}$ & $\begin{array}{l}23 \\
(23.24 \%)\end{array}$ & $\begin{array}{l}99 \\
(78.57 \%)\end{array}$ \\
\hline Total (\%) & $\begin{array}{l}67 \\
(53.17 \%)\end{array}$ & $\begin{array}{l}25 \\
(19.84 \%)\end{array}$ & $\begin{array}{l}9 \\
(7.15 \%)\end{array}$ & $\begin{array}{l}126 \\
(19.84 \%)\end{array}$ & $(100 \%)$ \\
\hline
\end{tabular}

Table 7.2: Krishi Prabha

\begin{tabular}{|c|c|c|c|c|c|}
\hline Students & $\begin{array}{l}\text { Online full text } \\
\text { journals } \\
\text { collection for } \\
\text { agriculture } \\
\text { sciences }\end{array}$ & $\begin{array}{l}\text { Online full text } \\
\text { e-Thesis } \\
\text { collection for } \\
\text { agriculture } \\
\text { sciences }\end{array}$ & $\begin{array}{l}\text { Online full } \\
\text { text e-Book } \\
\text { collection for } \\
\text { agriculture } \\
\text { sciences }\end{array}$ & $\begin{array}{l}\text { Don't } \\
\text { Know }\end{array}$ & Total \\
\hline $\begin{array}{l}\text { Research } \\
\text { Scholars }\end{array}$ & $\begin{array}{l}6 \\
(22.22 \%)\end{array}$ & $\begin{array}{l}19 \\
(70.37 \%)\end{array}$ & $\begin{array}{l}0 \\
(0 \%)\end{array}$ & $\begin{array}{l}2 \\
(7.41 \%)\end{array}$ & $\begin{array}{l}27 \\
(21.43 \%)\end{array}$ \\
\hline $\begin{array}{l}\mathrm{PG} \\
\text { students }\end{array}$ & $\begin{array}{l}24 \\
(24.24 \%)\end{array}$ & $\begin{array}{l}24 \\
(24.24 \%)\end{array}$ & $\begin{array}{l}14 \\
(14.14 \%)\end{array}$ & $\begin{array}{l}37 \\
(37.38 \%)\end{array}$ & $\begin{array}{l}99 \\
(78.57 \%)\end{array}$ \\
\hline Total $(\%)$ & $\begin{array}{l}30 \\
(23.81 \%)\end{array}$ & $\begin{array}{l}43 \\
(34.13 \%)\end{array}$ & $\begin{array}{l}14 \\
(11.11 \%)\end{array}$ & $\begin{array}{l}39 \\
(30.95 \%)\end{array}$ & $\begin{array}{l}126 \\
(100 \%)\end{array}$ \\
\hline
\end{tabular}

Consortium for e-Resources in Agriculture (CeRA) is one of the important sources of online journals in Indian agricultural universities and institutions. All the Indian agricultural libraries of State Agriculture Universities and ICAR Institutions are accessing online international journals through CeRA. The table-7.3 shows that $92.60 \%$ research scholars and $40.40 \%$ PG students are aware about CeRA. 
Table 7.3: CeRA

\begin{tabular}{|c|c|c|c|c|c|}
\hline Students & $\begin{array}{l}\text { Consortium for } \\
\text { e-thesis } \\
\text { Resources in } \\
\text { Agriculture }\end{array}$ & $\begin{array}{c}\text { Consortium } \\
\text { for } \\
\text { e-Resources } \\
\text { in Agriculture }\end{array}$ & $\begin{array}{c}\text { Complete } \\
\text { e-Resources } \\
\text { in } \\
\text { Agriculture }\end{array}$ & $\begin{array}{l}\text { Don't } \\
\text { Know }\end{array}$ & Total \\
\hline $\begin{array}{l}\text { Research } \\
\text { Scholars }\end{array}$ & $\begin{array}{l}1 \\
(3.70 \%)\end{array}$ & $\begin{array}{l}25 \\
(92.60 \%)\end{array}$ & $\begin{array}{l}0 \\
(0 \%)\end{array}$ & $\begin{array}{l}1 \\
(3.70 \%)\end{array}$ & $\begin{array}{l}27 \\
(21.43 \%)\end{array}$ \\
\hline PG students & $\begin{array}{l}12 \\
(12.12 \%)\end{array}$ & $\begin{array}{l}40 \\
(40.40 \%)\end{array}$ & $\begin{array}{l}9 \\
(9.09 \%)\end{array}$ & $\begin{array}{l}38 \\
(38.39 \%)\end{array}$ & $\begin{array}{l}99 \\
(78.57 \%)\end{array}$ \\
\hline Total $(\%)$ & $\begin{array}{l}13 \\
(10.32 \%)\end{array}$ & $\begin{array}{l}65 \\
(51.59 \%)\end{array}$ & $\begin{array}{l}9 \\
(7.14 \%)\end{array}$ & $\begin{array}{l}39 \\
(30.95 \%)\end{array}$ & $\begin{array}{l}126 \\
(100 \%)\end{array}$ \\
\hline
\end{tabular}

e-Granth is union catalogue of holdings (i.e. books and other documents) of major Indian agricultural Libraries. It is online catalogue accessible to all the Indian agricultural libraries. It is found that $70.37 \%$ research scholars and $25.25 \%$ PG students are aware about e-Granth (Table 7.4).

Table 7.4: e-Granth

\begin{tabular}{|c|c|c|c|c|c|}
\hline Students & $\begin{array}{l}\text { Union catalogue } \\
\text { of holdings (i.e. } \\
\text { books and other } \\
\text { documents) of } \\
\text { major Indian } \\
\text { agricultural } \\
\text { Libraries }\end{array}$ & $\begin{array}{c}\text { Union } \\
\text { catalogue of } \\
\text { online journals } \\
\text { of major } \\
\text { Indian } \\
\text { agricultural } \\
\text { libraries }\end{array}$ & $\begin{array}{c}\text { Union } \\
\text { catalogue of } \\
\text { e-thesis of } \\
\text { major Indian } \\
\text { agricultural } \\
\text { libraries }\end{array}$ & $\begin{array}{l}\text { Don't } \\
\text { Know }\end{array}$ & Total \\
\hline $\begin{array}{l}\text { Research } \\
\text { Scholars }\end{array}$ & $\begin{array}{l}19 \\
(70.37 \%)\end{array}$ & $\begin{array}{l}7 \\
(25.93 \%)\end{array}$ & $\begin{array}{l}1 \\
(3.70 \%)\end{array}$ & $\begin{array}{l}0 \\
(0 \%)\end{array}$ & $\begin{array}{l}27 \\
(21.43 \%)\end{array}$ \\
\hline $\begin{array}{l}\text { PG } \\
\text { students }\end{array}$ & $\begin{array}{l}25 \\
(25.25 \%)\end{array}$ & $\begin{array}{l}20 \\
(20.20 \%)\end{array}$ & $\begin{array}{l}7 \\
(7.07 \%)\end{array}$ & $\begin{array}{l}47 \\
(47.48 \%)\end{array}$ & $\begin{array}{l}99 \\
(78.57 \%)\end{array}$ \\
\hline Total (\%) & $\begin{array}{l}44 \\
(34.92 \%)\end{array}$ & $\begin{array}{l}27 \\
(21.43 \%)\end{array}$ & $\begin{array}{l}8 \\
(6.35 \%)\end{array}$ & $\begin{array}{l}47 \\
(37.30 \%)\end{array}$ & $\begin{array}{l}126 \\
(100 \%)\end{array}$ \\
\hline
\end{tabular}

An abstract is a brief summary of a research article or any other document and is often used to help the reader quickly ascertain the paper's or document's purpose. The PG students should aware about abstract of articles. The table- 8 shows that most of the students i.e. $92.07 \%$ are aware about the abstract. 
Table 8: Abstract

\begin{tabular}{|l|l|l|l|l|l|}
\hline Students & $\begin{array}{l}\text { Brief summary } \\
\text { of article/ } \\
\text { document }\end{array}$ & $\begin{array}{l}\text { Entier full text } \\
\text { article/ } \\
\text { document }\end{array}$ & $\begin{array}{c}\text { Bibliography } \\
\text { information of } \\
\text { article/document }\end{array}$ & $\begin{array}{l}\text { Don't } \\
\text { Know }\end{array}$ & Total \\
\hline $\begin{array}{l}\text { Research } \\
\text { Scholars }\end{array}$ & $\begin{array}{l}26 \\
(96.30 \%)\end{array}$ & $\begin{array}{l}0 \\
(0 \%)\end{array}$ & $\begin{array}{l}1 \\
(3.70 \%)\end{array}$ & $\begin{array}{l}0 \\
(0 \%)\end{array}$ & $\begin{array}{l}27 \\
(21.43 \%)\end{array}$ \\
\hline $\begin{array}{l}\text { PG } \\
\text { students }\end{array}$ & $\begin{array}{l}90 \\
(90.91 \%)\end{array}$ & $\begin{array}{l}5 \\
(5.05 \%)\end{array}$ & $\begin{array}{l}3 \\
(3.03 \%)\end{array}$ & $\begin{array}{l}(1.01 \%) \\
(78.57 \%)\end{array}$ \\
\hline $\begin{array}{l}\text { Total } \\
(\%)\end{array}$ & $\begin{array}{l}116 \\
(92.07 \%)\end{array}$ & $\begin{array}{l}5 \\
(3.97 \%)\end{array}$ & $\begin{array}{l}4 \\
(3.17 \%)\end{array}$ & $\begin{array}{l}(0.79 \%) \\
(100 \%)\end{array}$ \\
\hline
\end{tabular}

Peer reviewed journals publish research articles after reviewed by experts in the subject. Peer reviewed journals are very important source of information in research. Students need to aware about peer reviewed journals for knowing the research in their subject field as well as publishing their own articles. It is found that $66.67 \%$ Research Scholars and $34.34 \%$ PG students are aware about peer reviewed journals (Table 9). Overall only $41.27 \%$ students know about peer reviewed journals.

Table9: Peer-reviewed journal

\begin{tabular}{|c|c|c|c|c|c|}
\hline Students & $\begin{array}{c}\text { Popular } \\
\text { article }\end{array}$ & $\begin{array}{c}\text { Articles } \\
\text { reviewed by } \\
\text { experts in the } \\
\text { subject field }\end{array}$ & $\begin{array}{c}\text { Articles both } \\
\text { popular and } \\
\text { reviewed by } \\
\text { experts in the } \\
\text { subject field }\end{array}$ & $\begin{array}{c}\text { Don't } \\
\text { Know }\end{array}$ & Total \\
\hline $\begin{array}{c}\text { Research } \\
\text { Scholars }\end{array}$ & 3 & 18 & 3 & 3 & 27 \\
\hline $\begin{array}{c}\text { PG } \\
\text { students }\end{array}$ & $31.11 \%)$ & $(66.67 \%)$ & $(11.11 \%)$ & $(11.11 \%)$ & $(21.43 \%)$ \\
\hline $\begin{array}{c}\text { Total } \\
(\%)\end{array}$ & $(31.32 \%)$ & $(34.34 \%)$ & $(12.12 \%)$ & $(22.22 \%)$ & $(78.57 \%)$ \\
\hline
\end{tabular}

According to the Merriam-Webster Online Dictionary, to "plagiarize" means to steal and pass off (the ideas or words of another) as one's own, to use (another's production) without crediting the source, to commit literary theft and to present as new and original an idea or product derived from an existing source. The table-10 shows that overall only $17.46 \%$ students aware about plagiarism. It is worth mentioned here that overall $53.97 \%$ students don't know about the plagiarism. The study shows that both Research Scholars and PG students have poor knowledge about plagiarism. 
Table 10: Knowledge of Plagiarism

\begin{tabular}{|l|l|l|l|l|l|}
\hline Students & \multicolumn{1}{|c|}{$\begin{array}{c}\text { Copyright } \\
\text { violation }\end{array}$} & Fair use & \multicolumn{1}{|c|}{ Plagiarism } & $\begin{array}{l}\text { Don't } \\
\text { Know }\end{array}$ & \multicolumn{1}{|c|}{ Total } \\
\hline $\begin{array}{l}\text { Research } \\
\text { Scholars }\end{array}$ & $\begin{array}{l}12 \\
(44.44 \%)\end{array}$ & $\begin{array}{l}0 \\
(0 \%)\end{array}$ & $\begin{array}{l}7 \\
(25.93 \%)\end{array}$ & $\begin{array}{l}8 \\
(29.63 \%)\end{array}$ & $\begin{array}{l}27 \\
(21.43 \%)\end{array}$ \\
\hline $\begin{array}{l}\text { PG } \\
\text { students }\end{array}$ & $\begin{array}{l}18 \\
(18.18 \%)\end{array}$ & $\begin{array}{l}6 \\
(6.06 \%)\end{array}$ & $\begin{array}{l}15 \\
(15.15 \%)\end{array}$ & $\begin{array}{l}60 \\
(60.61 \%)\end{array}$ & $\begin{array}{l}99 \\
(78.57 \%)\end{array}$ \\
\hline Total (\%) & $\begin{array}{l}30 \\
(23.81 \%)\end{array}$ & $\begin{array}{l}6 \\
(4.76 \%)\end{array}$ & $\begin{array}{l}22 \\
(17.46 \%)\end{array}$ & $\begin{array}{l}68 \\
(53.97 \%)\end{array}$ & $\begin{array}{l}126 \\
(100 \%)\end{array}$ \\
\hline
\end{tabular}

It was asked from students about the Internet explorer which is very popular web browser. It was found that $96.03 \%$ students are aware about Internet explorer (Table-11.1). Google is one of popular search engine. It was found that $96.03 \%$ students have also given right answer about the Google search engine (Table-11.2). Table-11.3 shows skills of using internet of students. About $58.73 \%$ students are very confident for using internet while $37.30 \%$ students are at somewhat level.

Table 11.1: Internet Explorer

\begin{tabular}{|l|l|l|l|l|l|}
\hline Students & $\begin{array}{l}\text { Operating } \\
\text { System }\end{array}$ & $\begin{array}{c}\text { Word processing } \\
\text { tools }\end{array}$ & $\begin{array}{l}\text { Electronic } \\
\text { journal }\end{array}$ & $\begin{array}{c}\text { Web } \\
\text { browser }\end{array}$ & \multicolumn{1}{|c|}{ Total } \\
\hline $\begin{array}{l}\text { Research } \\
\text { Scholars }\end{array}$ & $\begin{array}{l}1 \\
(7.41 \%)\end{array}$ & $\begin{array}{l}1 \\
(3.70 \%)\end{array}$ & $\begin{array}{l}0 \\
(0 \%)\end{array}$ & $\begin{array}{l}24 \\
(88.89 \%)\end{array}$ & $\begin{array}{l}27 \\
(21.43 \%)\end{array}$ \\
\hline $\begin{array}{l}\text { PG } \\
\text { students }\end{array}$ & $\begin{array}{l}(1.01 \%) \\
\text { Total (\%) }\end{array}$ & $\begin{array}{l}3 \\
(1.01 \%)\end{array}$ & $\begin{array}{l}0 \\
(0 \%)\end{array}$ & $\begin{array}{l}97 \\
(97.98 \%)\end{array}$ & $\begin{array}{l}99 \\
(78.57 \%)\end{array}$ \\
\hline
\end{tabular}

Table11.2: Google

\begin{tabular}{|c|c|c|c|c|c|}
\hline Students & $\begin{array}{c}\text { Operating } \\
\text { System }\end{array}$ & $\begin{array}{l}\text { Search } \\
\text { Engine }\end{array}$ & $\begin{array}{c}\text { Online } \\
\text { Journal }\end{array}$ & $\begin{array}{c}\text { Web } \\
\text { browser }\end{array}$ & Total \\
\hline $\begin{array}{l}\text { Research } \\
\text { Scholars }\end{array}$ & $\begin{array}{l}0 \\
(0 \%)\end{array}$ & $\begin{array}{l}25 \\
(92.59 \%)\end{array}$ & $\begin{array}{l}0 \\
(0 \%)\end{array}$ & $\begin{array}{l}2 \\
(7.41 \%)\end{array}$ & $\begin{array}{l}27 \\
(21.43 \%)\end{array}$ \\
\hline $\begin{array}{l}\text { PG } \\
\text { students }\end{array}$ & $\begin{array}{l}2 \\
(2.02 \%)\end{array}$ & $\begin{array}{l}96 \\
(96.97 \%)\end{array}$ & $\begin{array}{l}0 \\
(0 \%)\end{array}$ & $\begin{array}{l}1 \\
(1.01 \%)\end{array}$ & $\begin{array}{l}99 \\
(78.57 \%)\end{array}$ \\
\hline Total (\%) & $\begin{array}{l}2 \\
(1.59 \%)\end{array}$ & $\begin{array}{l}121 \\
(96.03 \%)\end{array}$ & $\begin{array}{l}0 \\
(0 \%)\end{array}$ & \begin{tabular}{|l|}
3 \\
$(2.38 \%)$ \\
\end{tabular} & $\begin{array}{l}126 \\
(100 \%)\end{array}$ \\
\hline
\end{tabular}


Table 11.3: Skills of using the Internet

\begin{tabular}{|l|l|l|l|l|l|}
\hline Students & \multicolumn{1}{|c|}{ Very } & \multicolumn{1}{|c|}{ Somewhat } & \multicolumn{1}{c|}{ A little } & Never done it & \multicolumn{1}{c|}{ Total } \\
\hline $\begin{array}{l}\text { Research } \\
\text { Scholars }\end{array}$ & $\begin{array}{l}16 \\
(59.26 \%)\end{array}$ & $\begin{array}{l}10 \\
(37.04 \%)\end{array}$ & $\begin{array}{l}1 \\
(3.70 \%)\end{array}$ & $\begin{array}{l}07 \\
(0 \%)\end{array}$ & $(21.43 \%)$ \\
\hline $\begin{array}{l}\text { PG } \\
\text { students }\end{array}$ & $\begin{array}{l}58 \\
(58.59 \%)\end{array}$ & $\begin{array}{l}37 \\
(37.37 \%)\end{array}$ & $\begin{array}{l}4 \\
(4.04 \%)\end{array}$ & $\begin{array}{l}0 \\
(0 \%)\end{array}$ & $\begin{array}{l}99 \\
(78.57 \%)\end{array}$ \\
\hline Total $(\%)$ & $\begin{array}{l}74 \\
(58.73 \%)\end{array}$ & $\begin{array}{l}47 \\
(37.30 \%)\end{array}$ & $\begin{array}{l}5 \\
(3.97 \%)\end{array}$ & $\begin{array}{l}0 \\
(0 \%)\end{array}$ & $\begin{array}{l}126 \\
(100 \%)\end{array}$ \\
\hline
\end{tabular}

Citation of articles is very important in academic and research for citing the articles. Students should aware about the information about reference like author, title of article, name of journal, volume and issue of journals. Questions were asked from students related to following reference.

Reference: Lewison, G. \& Paraje, G. (2009). The percentage of reviews in research output: A simple measure of research esteem. Research Evaluation, 18(2), 25-37.

It is observed that Research Scholars are aware about author of article (96.30\%), title of article (85.18\%), title of journal (92.59\%), volume (70.37\%) and issue (70.37\%) of journals (table-12) in the reference. The table-12 shows the response of PG students about author of article (72.73\%), title of article (47.47\%), title of journal (38.38\%), volume (26.26\%) and issue (24.24\%) of journals in the reference which is poor than Research Scholars. Overall $85.71 \%$ students are aware about the year of publication.

Table 12: Knowledge of citation/reference

\begin{tabular}{|l|l|l|l|l|l|l|l|}
\hline Students & $\begin{array}{l}\text { Author } \\
\text { (s) of the } \\
\text { Article }\end{array}$ & $\begin{array}{c}\text { Title of } \\
\text { the } \\
\text { Article }\end{array}$ & $\begin{array}{c}\text { Title of } \\
\text { the } \\
\text { Journal }\end{array}$ & $\begin{array}{c}\text { Year of } \\
\text { the } \\
\text { Publicati } \\
\text { on }\end{array}$ & Volume & $\begin{array}{c}\text { Issue } \\
\text { Number }\end{array}$ & Total \\
\hline $\begin{array}{l}\text { Research } \\
\text { Scholars }\end{array}$ & $\begin{array}{l}26 \\
(96.30 \%)\end{array}$ & $\begin{array}{l}23 \\
(85.18 \%)\end{array}$ & $\begin{array}{l}25 \\
(92.59 \%)\end{array}$ & $\begin{array}{l}27 \\
(100 \%)\end{array}$ & $\begin{array}{l}19 \\
(70.37 \%)\end{array}$ & $\begin{array}{l}19 \\
(70.37 \%)\end{array}$ & $\begin{array}{l}27 \\
(21.43 \%)\end{array}$ \\
\hline $\begin{array}{l}\text { PG } \\
\text { students }\end{array}$ & $\begin{array}{l}72 \\
(72.73 \%)\end{array}$ & $\begin{array}{l}47 \\
(47.47 \%)\end{array}$ & $\begin{array}{l}38 \\
(38.38 \%)\end{array}$ & $\begin{array}{l}81 \\
(81.82 \%)\end{array}$ & $\begin{array}{l}26 \\
(26.26 \%)\end{array}$ & $\begin{array}{l}24 \\
(24.24 \%)\end{array}$ & $\begin{array}{l}99 \\
(78.57 \%)\end{array}$ \\
\hline Total (\%) & $\begin{array}{l}98 \\
(77.78 \%)\end{array}$ & $\begin{array}{l}70 \\
(55.56 \%)\end{array}$ & $\begin{array}{l}63 \\
(50 \%)\end{array}$ & $\begin{array}{l}108 \\
(85.71 \%)\end{array}$ & $\begin{array}{l}45 \\
(35.71 \%)\end{array}$ & $\begin{array}{l}43 \\
(34.13 \%)\end{array}$ & $\begin{array}{l}126 \\
(100 \%)\end{array}$ \\
\hline
\end{tabular}

Library Activities are divided in various sections on the basis of functions. It will be use if library users/students aware about the library sections. Students are expected to aware above mentioned library sections, so that the students can utilize the maximum facility of the library. Table-13 shows the comparative percentage regarding knowledge of library sections. It is found that overall more Research Scholars are aware about library functions than PG students. It is found from the study that Rental is equally popular among all the students. 
Table 13: Library Sections and their functions

\begin{tabular}{|c|c|c|}
\hline \multirow[t]{2}{*}{ Library Sections (Functions) } & \multicolumn{2}{|l|}{ Correct Answers } \\
\hline & Research Scholars & PG Students \\
\hline Acquisition (Purchase of Books) & $17 \quad(62.96 \%)$ & $39(39.39 \%)$ \\
\hline Periodical (Purchase of periodicals) & $22(81.48 \%)$ & $63 \quad(63.63 \%)$ \\
\hline $\begin{array}{l}\text { Circulation (Issue/Return of General Text } \\
\text { Books etc) }\end{array}$ & $(77.76 \%)$ & $(58.58 \%)$ \\
\hline $\begin{array}{l}\text { Technical (Classification \& Cataloguing of } \\
\text { Documents) }\end{array}$ & $(66.67 \%)$ & $(29.29 \%)$ \\
\hline $\begin{array}{l}\text { Documentation (Online journal and } \\
\text { Databases access facility) }\end{array}$ & $(62.96 \%)$ & $(36.36 \%)$ \\
\hline Reference (Help the users in library) & $(77.78 \%)$ & $(61.612 \%)$ \\
\hline $\begin{array}{l}\text { Rental (Issue/Return of General Text Books } \\
\text { etc) }\end{array}$ & $(85.15 \%)$ & $(83.84 \%)$ \\
\hline Total Respondents & 27 & 99 \\
\hline
\end{tabular}

\section{Conclusion}

The study fulfills the major objective to know the influence of information literacy on students of the university. The skills \& knowledge of students to identify, locate and evaluate were assessed in the study. Knowledge of students about the information, information sources, university library, information searching, library consortia, Internet etc were also assessed in the study. A comparative study of the data between PG students and Research Scholars were carried out to know the influence of information literacy. The study shows that Research scholars are more information literate as compared to PG students. Research scholars are more comfortable in identifying the information need, searching the information, locating the information, finding the information and using the information in comparison to PG students. They save the time in finding the information. Research scholars are well aware about library sections, library resources and functions of library. Therefore, they use the library facility and resources properly. Research scholars are well aware about national level programs like CeRA, Krishi Prabha, eGranth etc. and utilizing more online resources PG students are required to orient about these resources. PG students are influenced by Google for finding information which is not a right choice to find quality information.

\section{References}

[1] American Library Association, Presidential Committee on Information Literacy. Final Report, Washington, DC, 1989.

[2] Barefoot, Betsy (2006). Bridging the Chasm: First-Year Students and the Library. Chronicle of Higher Education 52, B16

[3] CILIP (2004) Information literacy: definition. <http://www.cilip.org.uk/getinvolved/advocacy/information-literacy/Pages/definition.aspx> (Accessed on 14.08.2012)

[4] Chauhan, Suresh K, Prem Chand, and Murthy, TAV (2006). "Information literacy for Indian academicians: INFLIBNET initiatives." Journal of Library and Information Science 31, 45-52.

[5] Dunn, K. (2002). Assessing information literacy skills in the California State University: A progress report. The Journal of Academic Librarianship, 28, pp. 26-35. 
[6] Doshi, Ameet (2006), How gaming could improve information literacy. Computers in Libraries. 15-17.

[7] Garner, S.D. (Ed) (2006). Final Report of High-Level Colloquium on Information Literacy and Lifelong Learning Alexandria, Washington DC IFLA, located October 2007. <http://www.ifl a.org/III/wsis/ High-Level-Colloquium.pdf>

[8] Maughan, P. D. (2001). Assessing information literacy among undergraduates: A discussion of the literature and the University of California-Berkeley assessment experience. College \& Research Libraries, 62, pp. 71-85.

[9] Owusu-Ansah, E. K. (2004). Information literacy and higher education: Placing the academic library in the center of a comprehensive solution. The Journal of Academic Librarianship, 30, pp. 3-16.

[10] Radcliff, C. J., Jensen, M. L., Salem, Jr., J. A., Burhanna, K. J., \& Gedeon, J. A. (2007). A practical guide to information literacy assessment for academic librarians. Westport, CT: Libraries Unlimited.

[11] Sanford, S. (2000). Terry Crane: Inspiring connections. <http://www.centerdigitaled. com/converge/?pg=magstory\&id=3374> (Accessed on 24.2.2005) Sonley, V., Turner, D., Myer, S., \& Cotton, Y. (2007). Information literacy assessment by portfolio: A case study. Reference Services Review, 35, pp. 41-70.

*Corresponding author.

E-mail address: meetumitika@gmail.com 